\title{
Behavioural Differences of Dogs of Various Ages in Czech Households
}

\author{
E. BARANYIOVÁ ${ }^{1}$, A. HOLUB, M. TYRLÍK² ${ }^{2}$ B. JANÁČKOVÁ ${ }^{3}$, M. ERNSTOVÁ ${ }^{4}$
}

\author{
${ }^{1}$ University of Veterinary and Pharmaceutical Sciences, Brno \\ ${ }^{2}$ Faculty of Arts, Institute of Psychology, Masaryk University, Brno \\ ${ }^{3}$ Ministry of Agriculture of the Czech Republic, Prague \\ ${ }^{4}$ Pfizer, s.r.o.
}

Received August 27, 2003

Accepted June 17, 2004

\begin{abstract}
Baranyiová E., A. Holub, M. Tyrlík, B. Janáčková, M. Ernstová: Behavioural Differences of Dogs of Various Ages in Czech Households. Acta Vet. Brno 2004, 73: 229-233.

The aim of the study was to evaluate the behaviour of dogs of various ages as viewed by their owners in the Czech Republic. The data were obtained in a questionnaire. The dogs were divided by age as follows: 35 animals younger than one year (Y), 220 middle-aged dogs (M), and 12 dogs, seniors (S) older than 8 years (giant and large breed dogs were included in this group at 8 years, medium at 10 years, and small and toy breeds at 12 years of age). The following significant differences were found: young dogs were destructive (household items and gardens), they eliminated in the house more frequently and mounted people. They were fed more than twice a day, and were never described as nervous. Middle-aged dogs were more often than others described as dominant and were given treats. Old dogs were most frequently described as nervous, sometimes difficult to control, and excessively barking, whining and howling. On the other hand, they were more often described as protective of the house and household members, and they were most often walked unleashed. These differences are in agreement with earlier data on the ontogeny of dog behaviour, and show some changes in the co-existence of people and dogs of various ages in Czech households. Importantly, they serve as a basic information about behaviour problems that may be encountered in veterinary practice and show a need for client education programmes and preventive behavioural medicine in the country.
\end{abstract}

Young, middle-aged, old dogs, development, behavioural traits, questionnaire

The behaviour of an individual changes in the course of its life. In past decades this fact was reflected in a scientific concept of the postnatal development of behaviour in dogs divided into several periods (Scott and Marston 1950; Scott 1962). The first, postnatal period lasting two weeks, is characterized by total dependence on mother for food, temperature regulation, and elimination. The puppies spend about $90 \%$ time sleeping, and their social contacts are limited to mother. It is followed by transitional period (days 15-28) with eyes and ears opening, locomotion changing from crawling to walking and gradually less dependence on mother for food and elimination. Social contacts with mother and littermates increase in freguency and complexity. In the following socialization period between weeks 4 and 12 or 14, also weaning occurs. This period is characterized by seeking other social contacts and is behaviorally the most important stage in dog's life (Houpt 1991; Beaver 1999). Juvenile period ( $3^{\text {rd }}$ to $6^{\text {th }}$ month of age) with rapid growth gradually turns into puberty around 10 months of age, then into adulthood, the relatively longest life period. It is followed by senescence the onset of which is still difficult to assess. In past decades, dozens of different tests have been described for evaluation of biological age, especially in humans. They consist mostly of variables characterizing the development of physiological functions and statistically analyzed. They are directed towards the causal scheme: mechanisms of senescence - biological age - mortality, likelihood of death

\footnotetext{
Address for correspondence:

Doc. MVDr. Eva Baranyiová, CSc.

University of Veterinary and Pharmaceutical Sciences

Palackého 1-3, 61242 Brno

Czech Republic
}

Phone:+ 420541562791

E-mail: actavet@vfu.cz

http://www.vfu.cz/acta-vet/actavet.htm 
(Ďoubal and Klemera 1999). Nevertherless, senescence has not been sufficiently elucidated as yet. Similar analyses are scarce in dogs (Brace 1981; Reid and Peterson 2000). There is evidence about decreasing adaptability of dogs to stress situations, decreased performance and higher incidence of diseases at older age. However, it is difficult to detect when these changes begin to make themselves felt so as we can speak about senescence (Houpt and Beaver 1981; Hofecker 1983abc; Kraft 1998; Burkholder 1999). There is an arbitrary agreement that dogs may be considered seniors based not only on their chronological age but also on breed or size. Large and mixed breed dogs are ageing more rapidly than purebred dogs and medium size and small dogs (Patronek et al. 1997; Hoskins and McCurnin 1997; Kraft 1997, 1998, Burgholder 1999). Their ageing may be accompanied by changes in the regulation of the hypothalamus-pituitaryadrenocortical system, binding capacities of receptors in CNS structures (Rothuizen et al. 1993), accumulation of pigments in CNS, depletion of dopamine, neurodegenerative processes (Hoskins and McCurnin 1997), personality and learning changes (Riis et al. 1992). It is thus also reflected in decreased cognitive abilities and behaviour (Houpt and Beaver 1981; Hoskins and McCurnin 1997; Landsberg and Ruehl 1997; Bain et al. 2001; Frank 2003).

Despite the fact that behaviour and its age changes especially in the postnatal period have attracted much attention in recent years, it is useful to continue studies along this line. Our aim was to find how age changes in behaviour of dogs affect their coexistence with humans in Czech households.

\section{Materials and Methods}

We further analyzed data on dogs obtained from a modified questionnaire based on Askew (1997) and Podberscek and Serpell (1997) as described earlier (Baranyiová et al. 2001). The questionnaire was published in a monthly magazine "Náš pes". Most data came from its readers and the rest was obtained from clients of veterinary clinics. We obtained data about the age and breed of dogs, age of their acquisition, health status, type of family housing, family structure (numbers of adults and children, other dogs and other animals in the household), about the daily routine of the dogs (nutrition and feeding regime, walks, types of games, plays with people and other dogs), their obedience (following commands), other behaviour manifestations (including the negatively perceived behaviours such as aggression), and general assessment of the position of the dog in the household. We analyzed how frequently the behaviours were reported and how they differed among dogs of various ages.

This time we divided the population of dogs of known age $(n=267)$ into three groups. The first one $(n=35)$ comprised dogs aged up to 12 months (young), second group $(n=220)$, middle-aged, and, the third group $(n=12)$ seniors aged between 8 and 12 years (dogs of giant and large breeds aged 8 and more years, medium-sized breeds aged 10, and small and toy breeds from 12 years; Brace 1981; Kraft 1997, 1998; Burkholder 1999).

For statistical evaluation of the results we used the $\chi^{2}$ test from a statistical software SPSS v. 8.

\section{Results}

The age structure of our dog population was uneven. Young dogs formed $13 \%$ of the population under study. The most numerous was the group of adults or middle aged dogs (82\%). With advancing age the numbers of dogs decreased and only $4.5 \%$ were up to 14 years of age.

In the studied dog population structured by age, we found the following: the ownerdescribed behaviour of dogs was not different from that indicated earlier (B aranyiová et al. 2001): more than nine-tenths of the dogs were considered playful, they were viewed as family members, their owners spoke to them daily, communicated with them, had their photographs, and assumed that the dogs perceived their moods and vice versa they perceived moods of their dogs. More than three-fourths of the dogs were considered faithful, people shared their problems with dogs, took them along for travel and vacation. Other behaviours were mentioned less frequently.

However, we found significant relationships between the age category (young /Y/, middle-aged $/ \mathrm{M} /$ and Senior $/ \mathrm{S} /)$ and frequency of feeding $\left(\chi^{2}=28.764, \mathrm{df}=2, p<0.001\right)$, 
destruction of household items $\left(\chi^{2}=18.511, \mathrm{df}=2, p<0.001\right)$, destruction of gardens $\left(\chi^{2}=\right.$ $6.807, \mathrm{df}=2, p<0.033)$, elimination in the house $\left(\chi^{2}=9.580, \mathrm{df}=2, p<0.008\right)$, attempts to mount people $\left(\chi^{2}=5.853, \mathrm{df}=2, p<0.054\right)$, dominant behaviour $\left(\chi^{2}=7.395, \mathrm{df}=2, p=\right.$ $0,025)$, people sharing treats (food) with dogs $\left(\chi^{2}=11.567\right.$, df $=2, p=0.03$ ), excessive whining, barking and howling $\left(\chi^{2}=13.873, \mathrm{df}=2, p=0.001\right)$, dog sometimes hard to control $\left(\chi^{2}=10.611, \mathrm{df}=2, p=0.028\right), \mathrm{dog}$ leashed in the streets $\left(\chi^{2}=10.312, \mathrm{df}=2, p=0.006\right)$ and dog considered as protecting their owners $\left(\chi^{2}=7.397, \mathrm{df}=2, p=0.025\right)$.

a) the group of young $/ \mathrm{Y} /$ dogs differed from the other two groups by the following most frequently occurring traits: $31.7 \%$ (compared to $\mathrm{M}=6.8 \%$ and $\mathrm{S}=8.3 \%$ ) were fed more often than twice a day, $42.9 \%$ of them (compared to $\mathrm{M}=13.8 \%$ and $\mathrm{S}=8.3 \%$ ) destroyed household items, $39.4 \%$ of them (compared to $\mathrm{M}=20.0 \%$ and $\mathrm{S}=33.3 \%$ ) destroyed gardens, $35.3 \%$ (compared to $\mathrm{M}=14.2 \%$ and $\mathrm{S}=41.7 \%$ ) eliminated in the house, $47.1 \%$ (compared to $\mathrm{M}=27.7 \%$ and $\mathrm{S}=41.7 \%$ ) attempted to mount people. Most of these dogs, namely $85.7 \%$ (compared to $\mathrm{M}=65.9 \%$ and $\mathrm{S}=50.0 \%$ ), were acquired in their socialization period, i.e. between the 6th and 10th week of life. Young dogs were never described as nervous.

b) Middle-aged (M) dogs, were more frequently considered dominant - in $40.1 \%$ cases (compared to $\mathrm{Y}=16.7 \%, \mathrm{~S}=11.0 \%$ ), and in $83.6 \%$ (against $\mathrm{Y}=58.8 \%$ and $\mathrm{S}=75.0 \%$ ) were given treats.

c) Seniors - old dogs were characterized more often by specific, mostly negatively perceived traits. Two thirds of them $(66.7 \%$ ) (compared to $\mathrm{Y}=12.1 \%$ and $\mathrm{M}=25.1 \%$ ) whined, barked and howled excessively, $45.5 \%$ of them (compared to $\mathrm{Y}=29.4 \%$ and $\mathrm{M}=$ $14.4 \%$ ) were sometimes difficult to control. One third of them, $33.3 \%$ (compared to $\mathrm{Y}=$ $0.0 \%$ and $\mathrm{M}=22.5 \%$ ), were described as nervous. When walked in streets, only $2.4 \%$ of them were leashed (compared to $\mathrm{Y}=80.0 \%$ and $\mathrm{M}=80.5 \%$ ). Their protectiveness of household members and items $(83.3 \%)$ was perceived as a positive trait (compared to $\mathrm{Y}=$ $58.8 \%$ and $\mathrm{M}=80.5 \%$ ).

\section{Discussion}

As soon as 1981 Houpt pointed out the fact that during the individual development the coexistence of dogs with people undergoes critical phases. This happens around the dog's age of 3-to- 6 months. At this age the problems with destructive behaviour, chewing, biting and housebreaking usually deteriorate. Another problem period is the second year of life in dogs, especially males, when they mature socially and some of them tend to become aggressive. Problems appear also in aged dogs. These are usually connected with their aggression caused by chronic pain due to arthritis, degenerative disease of the locomotor apparatus or CNS, but also with inappropriate elimination in the house in dogs suffering from renal, gastrointestinal or cardiovascular disease. They may also be connected with other behaviours resulting from changes typical of old age such as deteriorating olfaction, sight and hearing, restlessness/waking at night, pathological mourning. These problems were also reported by our respondents for all three age categories of dogs. For example, the youngest group, aged up to one year showed in agreement with ontogeny of their behaviour a physiological need for biting and chewing connected with exploration and play (Lindell 1997; Melese 1999) that was reflected in destructing items in the house and garden. During sexual maturation they have more frequently shown masturbation and mounting people. Askew (1997) found $86 \%$ normal and $84 \%$ of problem dogs occasionally mounting people. However, the latter may accompany aggression or be a sign of conflict behaviour (Houpt 1997; Connolly 2002). Frequency of described behaviours in the early phase after arrival in the owner's families shows insufficient basic training and absence of owner education (e.g., Hunthausen and Seksel 2003). 
Senior dogs in our population were more often walked without leash; they were less active. In agreement with this notion is our report (Baranyiová et al. 2003) that seniors aged 12to- 15 years became victims of interdog aggression in only $1 \%$ of incidents. Ability of old dogs to perceive, process and remember information about their environment obviously diminished. Old dogs suffer from repeatedly described cognitive dysfunction (Land sberg and Ruehl 1997; Bain et al. 2001; Neilson et al. 2001; Frank 2003). Statistically significant evidence of these problems was also obtained in our population of dogs when respondents reported nervousness, excessive vocalization (whining, barking and howling) and sometimes difficult control of their dogs.

The results of our study show the occurrence of behaviours some of which the owners perceive as negative. However, these were mostly physiological behavioural patterns shown in a context unacceptable for the owners. Frequency of negatively perceived components of behaviour in dogs shows the necessity to provide professional counceling to dog owners in veterinary clinics so that the quality of the human-animal bond remains intact.

\section{Rozdíly v hodnocení chování mladých a dospělých psů v českých domácnostech}

Cílem studie bylo vyhodnotit chování psů v českých domácnostech. Data získaná anketou jsme rozdělili dle jejich věku do tří skupin. První tvořilo 35 mladých psů, ve věku do jednoho roku, druhou 220 jedinců věku středního a třetí 12 psů nejméně osm až dvanáct let starých (psy plemen obřích a velkých od osmi, středních od deseti a malých a trpasličích od dvanácti roků). Zaznamenali jsme následující věkové statisticky významné vztahy: psi nejmladší častěji poškozovali a ničili vybavení domácností i zahrad, znečištovali obytné plochy močením a skákali lidem na nohu. Byli častěji krmeni víc než dvakrát denně a nikdy nebyli pokládáni za nervózní. Psi středního věku pak byli častěji než ostatní popisováni jako dominantní a členové domácností se s nimi víc dělívali o pamlsky. Psi staří pak byli frekventněji označováni jako nervózní, vytýkalo se jim, že jsou těžko kontrolovatelní a byli viněni z toho, že nadměrně kňučí, štěkají a vyjí. Byli však častěji pokládáni i za ochránce a obránce členů a vybavení domácností a na ulicích byli nejméně často poutáni na vodítku. Uvedené rozdíly jsou v souladu se skutečnostmi, které byly o věkových ontogenetických proměnách chování psů již dřive uváděny a dokládají proměny vztahů a soužití členů českých domácností se svými psími druhy různého věku. Zároveň poukazují na některé problémy s chováním psů, které se mohou objevit ve veterinární praxi a ukazují na nezbytnost kvalifikovaného poradenství pro klienty, majitele psů a preventivní behaviorální medicíny.

\section{References}

ASKEW, HR 1997: Behandlung von Verhaltensproblemen bei Hund und Katze. Parey, Berlin. VII and 372 p.

BAIN, MJ, HART, BL, CLIFF, KD, RUEHL, WW 2001: Predicting behavioral changes associated with agerelated cognitive impairment in dogs. J Amer Vet Med Assn 218: 1792-1795

BARANYIOVÁ, E, HOLUB, A, JANÁČKOVÁ, B, ERNSTOVÁ, M 2001: Výpovědi chovatelů o psech v České republice. Veterinářství 51: 167-172

BARANYIOVÁ, E, HOLUB, A, MARTINÍKOVÁ, M, NEČAS, A, ZATLOUKAL, J 2003: Epidemiology of intraspecies bite wounds in dogs in the Czech Republic. Acta Vet Brno 72: 55-62

BEAVER, BV 1999: Canine Behavior: a Guide for Veterinarians. W. B. Saunders Company, Philadelphia. 355 p.

BRACE, JJ 1981: Theories of ageing. Vet Clin North Amer: Small Anim Pract 11: 811-814

BURKHOLDER, WJ 1999: Age-related changes to nutritional requirements and digestive function in adult dogs and cats. J Amer Vet Med Assn 215: 625-629

CONNOLLY, PB 2002: Reproductive behaviour problems. In Horwitz D, Mills, D, Heath, S (Eds): BSAVA Manual of Canine and Feline Behavioural Medicine. BSAVA, pp. 128-143

ĎOUBAL, S, KLEMERA, P 1999: Metody verifikace teorií stárnutí. Čs. Fysiol 48: 171-178

FRANK, A 2003: Kognitive Dysfunktionen beim Hund. Prakt Tierarzt 84: 184-190

GOLDSTON, RT 1981: Preface. Geriatrics and Gerontology. Vet Clin North Amer Small Anim Pract 11: 9-10

HOFECKER, G: Altern. Teil 1. Unsere Hunde 60, No 6, 1983: 8

HOFECKER, G: Altern. Teil 2. Unsere Hunde 60, No 7, 1983: 14 
HOFECKER, G: Altern. Teil 3. Unsere Hunde 60, No 8, 1983: 5

HOSKINS, JD, McCURNIN, DM 1997: Geriatric care in the late '90s. Vet Clin North Amer Small Anim Pract 27: 1273-1281

HOUPT, KA 1991: Domestic Animal Behavior for Veterinarians and Animal Scientists. 2nd Edition. Iowa State University Press, Ames, 408 p.

HOUPT, KA, BEAVER, B 1981: Behavioral problems of geriatric dogs and cats. Vet Clin North Amer: Small Anim Pract 11: 643-652

HOUPT, KA 1997: Sexual behavior problems in dogs and cats. Progress in companion animal Behavior. Vet Clin North Amer Small Anim Pract 27: 601-615

HUNTHAUSEN, W, SEKSEL, K 2003: Preventive behavioural medicine. In Horwitz D, Mills, D, Heath, S (Eds): BSAVA Manual of Canine and Feline Behavioural Medicine. BSAVA, pp. 49-60

KRAFT, W 1998: Einführung. In: Geriatrie bei Hund und Katze. Berlin. pp. 1-26

LANDSBERG, G, RUEHL, W 1997: Geriatric behavioral problems. Vet Clin North Amer Small Anim Pract 27: 1537-1559

LINDELL EM 1997: Diagnosis and treatment of destructive behavior in dogs. Progress in companion animal Behavior. Vet Clin North Amer Small Anim Pract 27: 533-547

MELESE, P 1999: How to stop chewing problems in puppies. Vet Med-US 94: 157-163

NEILSON, JC, HART, BL, CLIFF, KD, RUEHL, WW 2001: Prevalence of behavioral changes associated with age-related cognitive impairment in dogs. J Amer Vet Med Assn 218: 1787-1791

PATRONEK, GJ, WATERS, DJ, GLICKMAN, LT 1997: Comparative longevity of pet dogs and humans: Implications for gerontology research. J. Gerontol, Series A- Biol Sci and Med Sci 52: B171-B178

PODBERSCEK, AL, SERPELL, JA 1997: Environmental influences on the expression of aggressive behaviour in English Cocker Spaniels. Appl Anim Behav Sci 52: 215-227

REID, SWJ, PETERSON, MM 2000: Methods of estimating canine longevity. Vet Rec 147: 630-631

RIIS, RC, CUMMINGS, JF, LOEW, ER, DELAHUNTA, A 1992: Tibetan terrier model of canine ceroid lipofuscinosis. Am J Med Genetics 42: 615-621

ROTHUIZEN, J, REUL, JMH, VANSLUIJS, FJ, MOL, JA, RIJNBERK, A, DEKLOET, ER 1993: Increased neuroendocrine reactivity and decreased brain mineralocorticoid receptor-binding capacity in aged dogs. Endocrinology 132: 161-168

SCOTT, JP 1962: Critical periods in behavioral development. Science 138: 949-958

SCOTT, JP 1992: The phenomenon of attachment in human-nonhuman relationships. In: The inevitable bond. Examining scientist-animal interactions. Cambridge University Press, Cambridge. pp. 72-92

SCOTT, JP, FULLER, JL 1965: Genetics and the Social Behavior of the Dog. University of Chicago Press. Chicago SCOTT, JP, FULLER, JL 1974: Dog Behavior. The Genetic Basis. University of Chicago Press. Chicago.

SCOTT JP, MARSTON M-V 1950: Critical periods affecting the development of normal and maladjustive social behavior in puppies. J Genet Psychol 77: 25-60 